\title{
A National Legacy of Enslavement: An Overview of the Work of the Slavery, History, Memory, and Reconciliation Project
}

\author{
Kelly L. Schmidt \\ Jesuit Conference of Canada and the United States, Washington, DC, USA \\ SHMR-ResearchCoordinator@jesuits.org
}

\begin{abstract}
As the Jesuit mission in the United States expanded to the west in the early nineteenth century, the Society bought, owned, hired, sold, and forcibly moved enslaved people to support their activities. Enslaved people lived and labored at Jesuit schools, scholasticates, churches, and farms in Missouri, Kentucky, Louisiana, and Kansas. Aspects of their lives, including names and family relationships, can be gleaned from Jesuit and other archival materials. These records show what daily life was like for enslaved people owned by the Jesuits as they built communities, sought to protect their families, and resisted their enslavement. They negotiated with the Jesuits to be allowed to purchase their freedom; sued the Jesuits for their freedom in court; and ran away. Undertaken by the Jesuits of Canada and the United States, the Slavery, History, Memory, and Reconciliation Project endeavors to shed light on this history and its contemporary legacies while working with descendants of the people the Society of Jesus held in slavery to determine steps forward today.
\end{abstract}

\section{Keywords}

United States - slaveholding by churches or religious orders - slavery and the law Jesuit missions - Jesuit colleges - St. Louis University - enslaved people - family relationships and slavery - reconciliation

Three couples, Thomas (c.1780s-bet.1833 and 1852) and Mary (called Polly or Molly, c.1781-1852) Brown; Isaac (c.1798-1864) and Susanna (called Succy 
or Susan, c.180o-50) Queen-Hawkins; and Moses (c.1777-1862) and Nancy (c.1770s-bef.1865) Queen, huddled together in a flatboat that at times drifted and at other moments careened down the Ohio River in May 1823. ${ }^{1}$ They had already walked on foot for a month as the "rearguard" of a hierarchically arranged band of twelve Jesuit priests, novices, and brothers while traversing the approximately 273-mile mountainous terrain of the Cumberland Road from the Jesuits' White Marsh plantation in Maryland to Wheeling, Virginia. They drove heavy wagons laden with the goods with which the Jesuits intended to found a new mission in the West. When the party reached the Ohio River, their owner, Father Charles Van Quickenborne (1788-1837), hoping to spare the expense of taking a steamboat, ordered that two flatboats be lashed together by a double cord. Most could not swim, and none knew how to navigate the river. Rather than hire a pilot, Van Quickenborne purchased a river guidebook and commissioned Brother Charles Strahan (b.1796) to navigate. Cargo themselves, Tom, Molly, Isaac, Succy, Moses, and Nancy sat in one overloaded flatboat separated by a small partition wall from four horses and the baggage, while the Jesuits shared the other boat. The three couples clung to one another as the boats snagged on driftwood and were caught in trees. Isaac frequently came to the Jesuits' aid in rowing the group out of trouble when the boats drifted out of the current, especially at night. ${ }^{2}$ On one occasion, the small flotilla nearly collided with a passing steamboat. " "A clamor arose from the slaves; all jumped out of bed awoken by the rapid striking together of the beams and strongly agitated by the dim of the horses," Jesuit Felix Verreydt (1798-1883), one of the novices on the journey, later reflected. All hurried to save their own lives, until the calamity passed. ${ }^{4}$

On less eventful days, the enslaved passengers and their Jesuit owners saw little of one another, since a partition wall divided the two boats. Though he could not see them, Verreydt assumed, "As they were good people, I do

1 Tom, Mary, Moses, and Nancy were in their forties. Isaac and Susan were in their twenties. Gilbert J. Garraghan, The Jesuits of the Middle United States (Chicago: Loyola University Press, 1938), 84-85; Peter De Meyer, "Reminiscences of Pioneer Life," 1868, Box 2.0013, Folder 4, General Governance Collection MIS.2.oo1, Jesuit Archives and Research Center, St. Louis, Missouri [hereafter JARC]; Felix Verreydt, "Memoirs," c.187o, Felix Verreydt Personnel File, JARC; Walter Hill, "Historical Sketches by Walter Hill, SJ," n.d., Walter Hill Personnel Files, JARC; Peter Verhaegen, "History of the Missouri Mission of the Society of Jesus," c.184os-188os, Box 2.0013, Folder 2, General History Collection, JARC, 2 .

2 Verhaegen, "History of the Missouri Mission." Verreydt writes, "One boat was laden with all our moveables, four horses were staked in it [...]. Beside this heavy load, that did almost far to out balance our boat, were the six colored people, making a pretty heavy load by themselves."

3 Verhaegen, "History of the Missouri Mission," 23.

4 Verhaegen, "History of the Missouri Mission." 
not doubt, they were saying their beads in a corner of their boat." ${ }^{5}$ We know some of what Jesuits such as Verreydt thought because they wrote it down. The thoughts of the enslaved people were not recorded, but we can imagine that as they prepared meals for their owners and assisted in navigation, the three couples prayed, yearned for the family and community they left behind, and worried about the unknown future before them. Moses and Nancy grieved over their separation from their children, who remained in Maryland. ${ }^{6}$ Isaac and Susan, newlyweds, wondered what it would be like to start a new family in an unfamiliar region far from their kin who remained in Maryland. ${ }^{7}$ All had left behind close relatives, including brothers and sisters. ${ }^{8}$ None knew whether they would ever see their families again. They must have dreamed of the freedom that was so close, on the northern bank of the river they traversed. Once settled for several years at their destination in Missouri, Verreydt commented, "We heard sometimes their earnest desire to be free in a free country, it was difficult not to say almost impossible to convince them of their happiness." 9

Jesuit historians have long known that Jesuits brought with them six enslaved people from their White Marsh plantation in Maryland to their new novitiate and missionary headquarters in Missouri in 1823. When Louis William Valentine DuBourg (1766-1883), bishop of Upper Louisiana and the Two Floridas, requested in 1823 that the Maryland Jesuits come to Missouri to establish a novitiate and farm in Florissant, he stipulated that they bring with them "at least four or five or six negroes, to be employed in preparing \& providing the additional Buildings, that may be found necessary, and in cultivating the land of the above mentioned Farm."10 In response, on April 10, 1823, the Corporation of Roman Catholic Clergymen of Maryland (the Society of Jesus in Maryland) transferred to Van Quickenborne, "Tom \& Polly his wife, Moises \& Nancy his wife, Isaac \& Succy his wife all of whom are the property

5 Verreydt, "Memoirs."

6 Hill, "Historical Sketches by Walter Hill, SJ," 23.

7 "Register of Baptisms, White Marsh," Maryland Province Archives [hereafter MPA].

8 Father James Van de Velde wrote that the enslaved people sold from Georgetown to Louisiana in 1838 "have near relations, brothers, sisters \& c at Florissant." James Van de Velde to Thomas Mulledy, March 28, 1848, MPA (Georgetown Slavery Archive, https://slaveryarchive. georgetown.edu/items/show/3 [accessed June 6, 2020]); Hill, "Historical Sketches."

9 Verreydt, "Memoirs."

10 Concordat regarding the Missouri Mission between Charles Neal and William Du Bourg, handwritten duplicates, circa 1823, 1886, Box 2.0021, Folder 1. General Governance Collection, MIS.2.oo1. JARC; Maryland Provincial's Instructions to Charles Felix Van Quickenborne, 1823, Box 2.0018, Folder 2. General Governance Collection, MIS.2.0018. JARC. 
of the above Corporation, with permission to transport them into the State of Missouri and there employ them in his service."11

Yet, while more contemporary Jesuits have been aware of the presence of slavery in its Midwestern and Southern missions, few have given it much attention. Nor has this history been widely known beyond the Jesuits. The Slavery, History, Memory, and Reconciliation (SHMR) Project acknowledges records the Jesuits left behind about their slaveholding, and pushes beyond them, aiming to more thoroughly uncover and understand the lived experiences of the people held in slavery to the Jesuits. The project began as a joint initiative of the Jesuits USA Central and Southern Province and Saint Louis University in 2016 and has since grown into a national effort supported by the Jesuit Conference of Canada and the United States. Jesuits have recognized the need to understand and share more fully their history of slaveholding throughout the United States. Thus, this essay offers an overview of the lesser-known lives of people whose enslavement sustained the Jesuits beyond Maryland and Pennsylvania. At present, we have determined that nineteenth-century Jesuits owned, rented, and borrowed more than 189 individuals in their Missouri, Kentucky, Louisiana, Alabama, and Kansas missions. That number grows, sometimes daily, as we continue to learn more. Through historical and genealogical research, the project also works to connect with living descendants of people the Jesuits held in slavery so that they can lead the Jesuits toward a path forward in acknowledging historical harms, repairing relationships, and working within our communities to address the legacies of slavery that persist in the form of racial inequities today.

Slavery was a total institution; it did not operate in isolation. Jesuit slaveholding was interconnected across parishes, missions, and schools throughout the nineteenth-century United States. Enslaved people were borrowed from and loaned to other religious orders, diocesan bishops and clergy, lay people, and non-Catholics. Jesuit institutions relied on other institutions, like contractors, banks, and benefactors, that benefited from enslaved labor. In this way, Jesuits were no different from their contemporaries: they were participants in local, national, and global systems of slavery that were-that are-inextricably bound to the origin story of the United States and tied to the participation of the Society of Jesus and the Catholic Church in slavery and the slave trade worldwide. Parishes, schools, and other works of the Catholic Church and its members share in this complicity of slaveholding. Likewise, the legacies of enslavement endure: just as descendant communities continue to be affected

11 Transfer of Slaves by Corporation of Roman Catholic Clergymen of Maryland to Father Charles Felix Van Quickenborne, Contract, April 10, 1823, Box 2.0018, Folder 1. General Governance Collection, MIS.2.0o1. JARC. 
by slavery's consequential structural racism, so too have Jesuit institutions continued to benefit.

The first step toward reconciliation in a Catholic context is confession and acknowledgement of one's sins, so we have begun by sharing what we know, as Jesuits express their remorse. When the project began, all we knew were the first names of about eight individuals in Missouri. Now we know that the Jesuits owned, rented, or borrowed closer to two hundred individuals, in what is now the central and southern United States. Moreover, we have identified surnames for most of the enslaved people owned by the Jesuits in these regions, which further enables us to proceed on a genealogical front toward connecting with descendants of the enslaved today. We have been sharing our historical findings with descendants and the public through letters, phone calls, meetings, articles, talks and conferences, on the web (http://shmr.jesuits.org) and on social media (@SHMRJesuits on Facebook, Instagram, and Twitter). We are learning from descendants we have met and are inviting descendants and others to share their stories and contribute to our efforts to address the legacies of slavery present in society today.

\section{Our Findings}

What we have learned is that enslaved people supported the growth of the Jesuit order in the expanding United States. They were at the heart of the running of the Jesuits' parishes, their missions to Native Americans and EuropeanAmerican settlers, as well as the development of their institutions of higher learning, including those established in the North. Although the Jesuits had established regulations intended to ensure more humane treatment of enslaved people, these regulations had more to do with conforming Jesuit slaveholding to Catholic teaching and moral law and justifying holding people in bondage as a means to lead them to salvation. In reality, the experiences of enslaved people hardly differed from those of other bondspeople, because the Jesuits were no different in how they treated enslaved people than other slaveholders. Jesuits frequently broke their own regulations about physically punishing bondspeople, splitting up families, and providing basic necessities such as adequate food and shelter.

Nevertheless, although the Jesuits attempted to dictate enslaved people's lives, they did not fully control the boundaries of these enslaved communities; enslaved people interacted with fellow bondspeople and other settlers and indigenous people around them, establishing roots in each area that endured even after they became free. Enslaved people used these networks 
to survive, surmount, and resist their enslavement. The Catholicism many bondspeople practiced, often inherited from previous generations who had the faith imposed on them from clergy owners, did not result in blind adherence to Jesuit owners, as some scholars have argued. Instead, enslaved people used their conceptions of their faith, as well as their owners' understanding of Catholicism, to resist their enslavement and to build and protect their families and kin communities. ${ }^{12}$

Thomas and Molly Brown, Moses and Nancy Queen, and Isaac and Susan Queen-Hawkins were six of the thousands of people the Jesuits held in slavery globally over the course of their history. Their forced journey to Missouri extended the presence of Jesuit slaveholding beyond Maryland, bringing it back to a region where the Jesuits had held people in bondage previously. Prior to the Jesuits' suppression, English Jesuits relied on indentured and enslaved labor in Maryland and Pennsylvania at sites including White Marsh, Fingale, Saint Thomas, Port Tobacco, Newtown, Saint Inigos, Saint Joseph, Bohemia, Tuckahoe, Deer Creek, Queenstown, Conewago, and Goshenhoppen beginning in the seventeenth century. ${ }^{13}$ French Jesuits had exploited enslaved labor most extensively on cash crop plantations in the Caribbean, but also relied on enslaved people in Canada and the Great Lakes region, and on plantations in what are now Kaskaskia, Illinois, and New Orleans, Louisiana. French Jesuits became among the largest slaveholders on the sugar island of Martinique, and were influential in shaping the Code Noir, the black codes that dictated enslaved lives in the French colonies. ${ }^{14}$ In 1727 , they also forced bondspeople

12 Randall M. Miller, "The Failed Mission: The Catholic Church and Black Catholics in the Old South," in Catholics in the Old South: Essays on Church and Culture (Macon, GA: Mercer University Press, 1999); For more on how enslaved people owned by the Jesuits in Missouri may have regarded their faith, and used religious services and the sacraments to solidify and protect kin communities, see Kelly L. Schmidt, “Enslaved Faith Communities in the Jesuits' Missouri Mission," U.S. Catholic Historian, special issue: Church and Slavery, 37, no. 2 (Spring 2019): 49-82.

13 Nicholas P. Cushner, Soldiers of God: The Jesuits in Colonial America, 1565-1767 (Buffalo, NY: Language Communications, 2002), 147. See Sharon M. Leon, "Life and Labor under Slavery: The Jesuit Plantation Project," Jesuit Plantation Project, https://jesuitplantationproject.org/s/ jpp/page/welcome (accessed June 6, 2020); Edward F. Beckett, Listening to Our History: Inculturation and Jesuit Slaveholding (St. Louis, MO: Seminar on Jesuit Spirituality, 1996); Curran, Bicentennial History of Georgetown University; Thomas Murphy, Jesuit Slaveholding in Maryland, 1717-1838 (New York: Routledge, 2001); Robert Emmett Curran, "Peter Kenney: Twice Visitor of the Maryland Mission (1819-21, 1830-33) and Father of the First Two American Provinces," in With Eyes and Ears Open: The Role of Visitors in the Society of Jesus, ed. Thomas M. McCoog, Jesuit Studies, 21 (Leiden: Brill, 2019), 191-213, here 205.

14 Robert W. Harms, The Diligent: A Voyage through the Worlds of the Slave Trade (New York: Basic Books, 2002), 24-28. 
from their plantations in Saint-Domingue to their newfound New Orleans plantation to cultivate sugarcane, figs, oranges, and other crops that would supply the Jesuits funds to expand their missionary efforts toward Native Americans as well as their educational institutions in colonial North America. The Jesuits in Louisiana owned an estimated 140 enslaved people on their New Orleans plantations at the time of their suppression in 1763 . They also forcibly conveyed forty-eight of their bondspeople in Kaskaskia on a treacherous journey to New Orleans in response to the royal decree of their expulsion. Adults and children, among them Ursula, Stanislaus, Borgia, Joachim, Rosalie, Jerome, Cyprian, Christopher, Bazile, Chrysostom, and Gabriel, were auctioned away. ${ }^{15}$

The Society of Jesus participated extensively in slaveholding and the slave trade globally, almost since the order's founding, and remained involved until slavery's abolition as it occurred in different parts of the world. Early Jesuits, including co-founders Ignatius Loyola $(c .1491-1556)$ and Diego Laínez (151265 ), discussed the use of enslaved labor in India and Japan. Simão Rodrigues (1510-79), Francis Xavier (1506-52), Matteo Ricci (1552-1610), and many other Jesuits relied on indigenous and African enslaved people in Portugal, India, Japan, and China. Jesuits were extensively involved in the slave trade in Angola, as elsewhere, and owned 5,10o people on their estates in Mozambique. Jesuits were especially large slaveholders in the Caribbean and South America, and even when they did not directly hold people in slavery, collaborated with European governments in expanding slavery in their colonial missions. ${ }^{16}$ As

15 Albert Hubert Biever, The Jesuits in New Orleans and the Mississippi Valley: Jubilee Memorial (Society of Jesus in Louisiana, 1924), 35-36; Jesuit Relations, 70:243-425; "Expulsion of the Jesuits from Louisiana in 1763," Woodstock Letters 6 (1877): 19-24; Roger Baudier, The Catholic Church in Louisiana (New Orleans: n.p., 1939): 164-65; Stephan Lenik, "Mission Plantations, Space, and Social Control: Jesuits as Planters in French Caribbean Colonies and Frontiers," Journal of Social Archaeology 12, no. 1 (February 1, 2012): 51-71; Eric Hinderaker, Elusive Empires: Constructing Colonialism in the Ohio Valley, 1673-180o (Cambridge: Cambridge University Press, 1999), 98.

16 The following citations are far from an exhaustive selection of the plentiful scholarship on Jesuit slaveholding globally: Rômulo da Silva Ehalt, "Jesuit Arguments for Voluntary Slavery in Japan and Brazil," Revista brasileira de história 39, no. 8o (April 2019): 87-107, here 7; Dauril Alden, "Those Who Also Served: Bondsmen and Lay Servants," in The Making of an Enterprise: The Society of Jesus in Portugal, Its Empire, and beyond: 1540-1750 (Stanford, CA: Stanford University Press, 1996), 502-27; letter from Francis Xavier to Gaspar Barzeas, October 25, 1552, M. Costelloe, trans., published in M. Joseph Costelloe, The Letters and Instructions of Francis Xavier (St. Louis, MO: Institute of Jesuit Sources, 1992), 445-47; Matteo Ricci, Della entrata della Compagnia di Giesù e Christianità nella Cina, ed. Piero Corradini and Maddalena del Gatto, trans. Nicholas Lewis and Philip Gavitt (Macerata: Quodlibet, 200o); Festo Mkenda, "Jesuits and Africa," Oxford Handbooks Online, August 3, 2016, https://doi. org/10.1093/oxfordhb/9780199935420.o13.56; Festo Mkenda, "Jesuit Historiography in Africa," 
such, all Jesuits and their institutions are inheritors of the Jesuit legacy of slaveholding. The pages that follow examine the history of the enslaved people the Jesuits exploited in the central and southern United States, to illuminate one piece of this global history of enslavement and its legacies.

\subsection{The Missouri Mission}

The Browns, Queens, and Hawkinses were relieved when their flatboat navigating the Ohio River landed at last in Shawneetown, Illinois, though their relief was fleeting. The conditions they left in Maryland were abysmal, their trip terrifying, and their new, foreign situation promised to be difficult as well. ${ }^{17}$ The band of bondspeople and Jesuits walked on foot through Illinois, which had been a free state for fewer than five years, to Saint Louis, where, with the permission of DuBourg, they settled on a farm in Florissant, Missouri, a village northeast of Saint Louis, where the Jesuits named their new novitiate Saint Stanislaus. The Jesuits took the farmhouse, while Tom, Molly, Moses, Nancy, Isaac, and Susan shared a small cabin that also served as the kitchen and washhouse, and had no loft. ${ }^{18}$ From this space, the three enslaved couples began to build the Jesuits' missionary outpost in the West. Susan prepared meals, and Molly and Nancy performed domestic work such as sewing and laundering. Moses served as a "jack of all trades," and along with others performed additional labor at night for pay, while Thomas, Isaac, and others hewed logs and stone to build new structures on the farm, and

Jesuit Historiography Online, ed. Robert A. Maryks, https://referenceworks.brillonline. com/entries/jesuit-historiography-online/jesuit-historiography-in-africa-COM_192529 (accessed June 6, 2020); William Francis Rea, "Agony on the Zambezi: The First Christian Mission to Southern Africa and Its Failure 1580-1759," Zambezia 1, no. 2 (1970): 46-53, here 5\%; Nicholas P. Cushner, "Slave Mortality and Reproduction on Jesuit Haciendas in Colonial Peru," The Hispanic American Historical Review 55, no. 2 (1975): 177-99; Brendan J. M. Weaver, "Perspectivas para el desarrollo de una arqueología de la diáspora africana en el Perú: Resultados preliminares del proyecto arqueológico haciendas de Nasca," Allpanchis 43, no. 80, 2 (2012): 85-120; Weaver, "Rethinking the Political Economy of Slavery: The Hacienda Aesthetic at The Jesuit Vineyards of Nasca, Peru," Post-Medieval Archaeology 52, no. 1 (2018): 117-33; Yannick Le Roux, Réginald Auger, and Nathalie Cazelles, Loyola, les jésuites et l'esclavage l'habitation des jésuites de Rémire en Guyane française (Québec: Presses de l'Université du Québec, 2009); Sherwin K. Bryant, "Enslaved Rebels, Fugitives, and Litigants: The Resistance Continuum in Colonial Quito," Colonial Latin American Review 13, no. 1 (June 1, 2004): 7-46; Herman W. Konrad, A Jesuit Hacienda in Colonial Mexico: Santa Lucía, 1576 1767 (Stanford, CA: Stanford University Press, 1980).

17 See Robert Emmett Curran, The Bicentennial History of Georgetown University (Washington, DC: Georgetown University Press, 1993), 130-31.

18 Peter De Meyer, "Reminiscences of Pioneer Life," 1868, 25-26; Verreydt, "Memoirs"; Hill, "Historical Sketches," 35-37. 
began cultivating the farmland. ${ }^{19}$ As they worked the land and attended Mass at the nearby Saint Ferdinand Church, they encountered unfamiliar creole populations of French, Spanish, Native American, and African heritage.

Over time, their community grew, by birth, marriage, purchase, and the arrival of more families from Maryland. Moses and Nancy Queen, Isaac and Susan Queen-Hawkins, and Thomas and Molly Brown rejoiced when reunited with relatives in 1829 , when Van Quickenborne personally conveyed two families, Proteus (c.175os-1869) and Anny (unknown-1841) QueenHawkins, and Jack (unknown-1850) and Sally (c.1797-1857) Queen, and the children of both couples-about sixteen people total-from White Marsh to Florissant. ${ }^{20}$ Although overjoyed at their reunion, their arrival evoked a mixture of other emotions: while the Queens and Hawkinses were related to most of the first six enslaved people who had helped found the mission in Missouri, their reunion was bittersweet because it also meant separation from brothers, sisters, and other family in Maryland, many of whom were among the more than 272 enslaved people sold by the Jesuits of the Maryland Province in 1838 to pay off growing debts. ${ }^{21}$ Moses and Isaac, among others, frequently requested to go home to see their loved ones, but most were never to see their families again. ${ }^{22}$

By 1829, when the Missouri Jesuits took over operation of Saint Louis College (which became a university in 1832) in downtown Saint Louis, they owned at least twenty-six enslaved people. By 1830, about six people, including Thomas and Molly Brown, had been sent to work at the new college, while most remained on the Jesuits' seminary and farm in Florissant to support the school and local Jesuit parishes. A few bondspeople labored at Saint Ferdinand Parish in Florissant, and Saint Charles Borromeo Parish in Saint Charles, Missouri. A few others involuntarily joined the Jesuits on missionary

19 Garraghan, Jesuits of the Middle United States, 10o; Verreydt, "Memoirs"; Hill, "Historical Sketches," 41.

20 Jesuits recorded Proteus Hawkins to be between one hundred and 120 years of age at his death, based on Proteus's own claims about his age and that he was "a ploughboy" during the American Revolution. Verreydt, "Memoirs"; Garraghan, Jesuits of the Middle United States, 613; Joseph Zwinge, "Jesuit Farms in Maryland: Facts and Anecdotes, the Negro Slaves," Woodstock Letters 41 (1912): 276-91; Hill, "Historical Sketches," 51.

21 There were also smaller sales that may have broken up their families. Van de Velde to Mulledy, March 28, 1848.

22 Charles Van Quickenborne to unidentified, October 11, 1826, Maryland State Archives film about Missouri Mission/Province [hereafter MSA], MSA M 1320, JARC; Charles Van Quickenborne to Francis Dzierozynski, November 17, 1828, MSA M 1320, JARC; Charles Van Quickenborne to Francis Dzierozynski, November 24, 1828, MSA M 1320, JARC. 
ventures to Portage des Sioux, Missouri, and to Potawatomi missions in Sugar Creek, Kansas. ${ }^{23}$

The Jesuits also shared enslaved people with local slaveowners, Catholic bishops and clergy, and the Sisters of the Sacred Heart and Sisters of Loretto, among other religious orders. ${ }^{24}$ One such individual was Charles (c.1791-unknown), whom Saint Louis bishop Joseph Rosati (1789-1843) considered his property. Charles had been sent to paint, whitewash, and plaster the convent of the Sisters of Saint Joseph of Cahokia, Illinois, and sued Rosati for his freedom. Soon after, Rosati made Jesuit Missouri Vice-Provincial Peter Verhaegen (180o-68) administrator of his estate, including his enslaved people, while he was abroad. Thus, Charles refiled the suit naming Verhaegen as the defendant, claiming Verhaegen had assaulted and falsely imprisoned him "with force and arms." ${ }^{25}$ Another was Edmund (c.1810-aft.1844), whom the Sisters of the Sacred Heart and the Jesuits brought with them to Sugar Creek, where Edmund assisted with the construction of buildings and taught the Potawatomi farming and carpentry. ${ }^{26}$ Because the Missouri Compromise of 1820 had outlawed slavery in the Louisiana Territory west of Missouri north of the $36^{\circ} 30^{\prime}$ latitude line, Edmund was legally free after both orders brought him to labor in Kansas. One of the sisters remarked, "Edmund showed the Indians where to put the gate in the center of the fence around the cemetery. I don't tell him he's free in Kansas, even though he would probably stay. I am being very careful not to let him

23 Missouri Mission Varia, Box 2.0157, Item 2. Office of the Treasurer Collection, unprocessed collection. JARC; 1830 United States Federal Census for St. Louis, St. Louis, Missouri. NARA microfilm publication Mig, roll 72. Records of the Bureau of the Census, Record Group 29, National Archives and Records Administration [hereafter NARA], Washington, DC, 336; "Tertius Liber Archivii Domus Probationis Sti. Stanislai Missionis S.J. Missourianae," 183273, Box 3.0148, Volume 3. Saint Stanislaus Seminary Collection, MIS.3.oo8. JARC; Verreydt, "Memoirs."

24 The Society of the Sacred Heart and the Sisters of Loretto, among other orders of women religious, have both been involved in similar projects to investigate their slaveholding. See "Our History of Slaveholding," https://rscj.org/history-slaveholding (accessed June 6, 2020); "Motherhouse History," Loretto Community, https://www.lorettocommunity.org/about/ history/motherhouse-history/ (accessed June 6, 2020). The involvement of women religious and slaveholding has recently received attention in the New York Times: Rachel L. Swarns, "The Nuns Who Bought and Sold Human Beings," August 2, 2019, https://www.nytimes. com/2019/o8/o2/opinion/sunday/nuns-slavery.html (accessed June 6, 2020).

"Charles, a man of color, vs. Peter Verhaegen," Missouri State Archives, 1841, 1842.

26 Garraghan, Jesuits of the Middle United States, 205-7; Lucille Mathevon, "Commencement de la Mission Indienne par les Religieuses du Sacré Coeur partie de St. Louis le 29 juin 1841,” Archives of the United States-Canada Province of the Society of the Sacred Heart [hereafter RSCJ]; Catherine de Tardieu, "Journal Sacred Heart Convent. St Mary's. Kan." (1872), RSCJ; Verreydt, "Memoirs." 
learn that he is free here, for even though he is content and perhaps too pious to take advantage of [his free status], he is nonetheless more certain (if that is possible) to leave it alone, if he remains ignorant of it." ${ }^{27}$ Meanwhile, back at the novitiate, bondspeople labored alongside Native American boys at the Jesuits' Saint Regis Indian School, both groups suffering beatings at the hands of the Jesuits when their labor did not meet Superior Van Quickenborne's expectations. ${ }^{28}$

Bondspeople continued to endure physical punishment, arduous labor, and poor housing conditions. Edmund's unstable cabin was susceptible to whirlwinds and almost destroyed by a tornado. Wood for new cabins at the Florissant novitiate lay rotting in a field. ${ }^{29}$ At Saint Louis University, Thomas Brown remarked in 1833 that the shelter provided by the Jesuit rector Peter Verhaegen for himself and his wife, Molly, was so poor, that Brown had "not a doubt but cold will kill both me and my wife here." Advocating that "I have been a faithful servant in the Society going on 38 years, \& my wife, Molly, has been born \& raised in the Society, She is Now about 52 years of Age," Brown lamented, "Now we have not a place to lay our heads in our old age after all our Service."30

Although the Jesuits mistreated them, the Jesuits' bondspeople were resilient. Bondspeople in Missouri frequently resisted their enslavement, and several sought to obtain their freedom. Members of the Brown, Hawkins, and Queen families in Missouri were part of a larger extended family experienced at pursuing their freedom. They descended from a network of active freedom-seekers who sued for their freedom in the courts of Washington, DC. ${ }^{31}$ Several sustained this agency in Missouri. When Thomas Brown wrote his letter regarding his and Molly's inadequate housing conditions, he petitioned Jesuit leadership in Maryland to allow him to buy their freedom for one hundred dollars, "as much as I can raise, \& as much as our old bones are worth." ${ }^{32}$ Another bondsman, Peter Queen-Hawkins (1824-c.1907), had made an arrangement with the Jesuits to purchase the freedom of himself and his wife, Margaret (c.1839-c.1869). Saint Louis University had purchased Margaret in 1862 from

27 Mathevon, "Commencement de la Mission Indienne par les Religieuses du Sacré Coeur partie de St. Louis le 29 juin 1841"; de Tardieu, "Journal Sacred Heart Convent. St Mary's. Kan."

28 Garraghan, Jesuits of the Middle United States, 147-69; Pierre-Jean De Smet to Peter Verhaegen, Florissant, June 11, 1830, MSA M 1320, JARC.

29 Verreydt, "Memoirs"; ARSI, Miss., 10o1-IV, fols. $215^{\mathrm{r}}-217^{\mathrm{r}}$, trans. Timothy Kieras.

30 Thomas Brown, October 21, 1833, MPA.

31 For more on the freedom suits of the Queen, Hawkins, and Brown families, see William G. Thomas, III et al., "Queen Family Network," O Say Can You See: Early Washington, D.C., Law \& Family, University of Nebraska-Lincoln, http://earlywashingtondc.org/families/queen (accessed August 10, 2020).

32 Thomas, "Queen Family Network." 
Charles G. McHatton (1811-95) for $\$ 800$ at Peter's request as a reward for being "the best slave." In allowing Peter to buy their freedom, the Jesuits stipulated that Peter must pay back Margaret's purchase price. In 1864, Peter complained that what the Jesuits were asking of him was too difficult to achieve. The Jesuits, in turn, grumbled that other bondspeople must have influenced Peter to be so dissatisfied. However, they agreed that Peter and Margaret either take their furnishings and go live as free people, sending back the remaining $\$ 400$ owed on Margaret's purchase as they earned it, or the couple could remain for two more years and pay off the cost with their labor. Peter and Margaret chose to stay. When the Jesuits decided to make contracts for the hired labor of four remaining families who had become free with Missouri's abolition of slavery in January 1865 , Peter and Margaret were among them, but did not receive pay until April 1867, effectively held in a state of debt peonage. ${ }^{33}$ In 1866 , Peter had requested that the Jesuits grant him a ten-acre plot of their land in Florissant for his own use, but the Jesuits denied it to him, deeming that it was inefficient. Nevertheless, Peter remained with the Jesuits in Florissant until close to the time of his death around $1907 \cdot{ }^{34}$

\subsection{Saint Mary's College, Lebanon, Kentucky}

As the Missouri mission expanded into a vice-province in 1840 and a province in 1863 , so too grew its slaveholding. In addition, French Jesuits had begun reestablishing their presence as missionaries in the United States, also supported by enslaved labor. In 1831, French Jesuits from Lyon accepted an offer from the bishop in Bardstown, Kentucky, to take over Saint Mary's College from the diocese. There, they relied upon enslaved labor to support the college, until its leadership left to take over Fordham University (then Saint John's College) in New York in 1846, and from there, founded the Canada Province. ${ }^{35}$

33 "Day book for the House and Farm," 1855-65, Box 3.0144, Folder 1. Saint Stanislaus Seminary Collection, MIS.3.oo8. JARC.

34 "Consultors Meeting Minutes for the Missouri Vice Province" (1832), Missouri Province Collection, unprocessed collection, JARC; "Bill of Sale for Margaret," December 26, 1862, Box 3.0223, folder 7-Slavery 1850, 1862, 1872. Saint Louis University Collection, MIS 3.002, JARC; Status Temporalis St. Louis, St. Joseph College, and St. Francis Xavier College, 1855-6. Folder D. Vol. 6, 404-6, JARC; William J. Grace, "Photographs of Brother Peter, in Album 25, Scrapbook by William J. Grace, S.J.," 1905, Box 2.0125. Missouri Province Scrapbook Collection, JARC; 1870 United States Federal Census for Saint Ferdinand, Saint Louis, Missouri. NARA microfilm publication M593_8og. Washington, DC: NARA, 265B; Baptisms, living Rosary, Rosary Sorority, Apostleship of Prayer, and Sacred Heart Devotion record book, 1864-1871, Box 3.0148, Folder 12. Saint Stanislaus Seminary Collection, MIS.3.0o8. JARC.

"Kentucky: Lebanon, St. Mary's College," n.d., Missouri 3.o111, JARC. 
The enslaved laborers at Saint Mary's College regularly worked alongside the college's students. The Jesuits prided themselves on the work ethic of their students, for whom it had been a rule since Saint Mary's founding to support the cash-strapped college with manual labor once a week, "to work upon the college farm in plowing, driving teams, chopping and sawing wood, assisting in harvesting and engaging in any other species of manual labor incident to life upon the farm." ${ }^{36}$ Enslaved laborers, however, continued to do the bulk of the work. Seventeen enslaved people supported the college as farm laborers and domestics, according to the 1840 census ${ }^{37}$ Bondspeople and students hewed trees to make fences and pens, raised cattle and horses, and tended to the cornfields. ${ }^{38}$ Bondspeople also supplied Jesuits and students with their meals. Writing of Saint Mary's College in 1843, Michael Nash, S.J. (1825-95), commented, "Hog killing time was a feature of every year. During this time our negro cooks gave us fine specimens of their culinary skill. They served us pork in every style, together with the inevitable, but always relished 'Corn-dodger;' and we grew healthy and contented on the plain but abundant fare." ${ }^{39}$ In 1838, the Jesuits expanded the college farm with the purchase of a neighboring farm. ${ }^{40}$ Enslaved people belonging to slaveowners in the area attended Saint Charles Church, near Saint Mary's College, with their owners. ${ }^{41}$ The Jesuits' enslaved people likely took these Sunday opportunities to intermingle with neighboring bondspeople, as they also did in Missouri and Louisiana.

On July 4, 1839, Saint Mary's College hosted an Independence Day celebration. Bondspeople worked under the direction of a few white carpenters to construct a spacious stage in a shady grove of trees big enough for all the members of the county to gather, using their labor to create a space where white attendees could leisurely enjoy presentations on American freedom, while the enslaved people served them food and drink. The irony was likely not lost on the enslaved people present. There, beginning at ten in the morning, the students paraded, gave speeches, performed dramatic acts, and sang patriotic songs. As a student commenced the event with a reading of the Declaration of

36 "Kentucky: Lebanon, St. Mary's College."

37 Sixth Census of the United States, 1840, for Marion, Kentucky (NARA microfilm publication M704, Roll 118). Records of the Bureau of the Census, Record Group 29. NARA, Washington, D.C, 343 .

38 Augustus J. Thebaud, Forty Years in the United States of America (1839-1885) (New York: The United States Catholic Historical Society, 1904), 72.

39 Michael Nash, "Reminiscences of Father Michael Nash," Woodstock Letters 26, no. 2 (1897): 257-86, here 263 .

40 "Kentucky: Lebanon, St. Mary's College," n.d., Missouri 3.o111, JARC.

41 Thebaud, Forty Years, 90. 
Independence to the crowd of hundreds, Jesuit Augustus Thebaud (1807-85) observed "a great number of jolly negroes, who had come with their masters and mistresses, stood on the extreme limits of the assemblage and attentively listened to the reading." ${ }^{42} \mathrm{He}$ commented that he

could not distinguish on their faces the effect produced on them when the words of Thomas Jefferson were read declaring that man has inalienable rights, and among them life, liberty, and the pursuit of happiness. But it is very probable that they drew no conclusions from those words as to their own rights. They appeared to be very happy, and when called on to bring refreshments to their masters they were not too closely watched nor prevented from taking their share of them..$^{43}$

Thebaud assumed the enslaved people were ignorant, denying their intelligence and cultural acuity. However, the enslaved attendants likely did hear this language about freedom and discussed what this rhetoric of freedom meant for them with one another, even if they did not let their sentiments show on their countenances to the white slaveowners present. While we may not know what they discussed, we do know that the enslaved people owned by the Jesuits in each region took steps to resist their enslavement and achieve freedom. Such was the case of Peter at Saint Joseph College in Bardstown.

\subsection{Saint Joseph College, Bardstown, Kentucky}

Jesuits from the Missouri Vice-Province returned to Kentucky in 1848 to take over Saint Joseph College, where, through their operation of the college until 1864, they relied upon the forced labor of up to twenty enslaved people at any given time. Some the Jesuits owned; others were loaned to them by the diocese and the local bishop and clergy. Some they hired from neighboring lay people, and some were loaned to the Jesuits on behalf of students in payment of their tuition. Jesuit John Baptist Duerinck wrote that "the Black boys sweep the house and mind the boys refectory," and commented that Peter Verhaegen (180o-68; as president of Saint Louis University, 1829-36; as president of Saint Joseph's College, $1845^{-51}$ ) used to grumble and scold the enslaved boys when the college's pigs got into the yard outside his window, and he would call upon one of them to drive them away. ${ }^{44}$

\footnotetext{
42 Thebaud, Forty Years, 141-44.

43 Thebaud, Forty Years, 141-44.

44 Duerinck to Druyts, September 21, 1848, Box 3.o11, folder 1. St. Joseph College Collection [hereafter SJC], MIS.3.007.
} 
Near the 185 os, the Jesuits also took two enslaved people from their novitiate in Missouri to Bardstown, Kentucky. One of these was a man named Peter. ${ }^{45}$ "Big" Peter, as he was called in Jesuit records, was purchased by the Jesuits in 1832, when he was about fifteen to seventeen years of age, from Louis Barada (1792-1852) of Saint Charles, Missouri. Part of Peter's purchase price of $\$ 513$ had been paid for in alms, likely from the Jesuit-operated Saint Ferdinand Church in Florissant. Peter may have been the son of Felicite (dates unknown), a woman enslaved to Barada, who had a son named Peter with a Spanish man named Antoine (dates unknown) in 1812. Peter labored on the Jesuits' farm, where he met Marian (b. c.1827), a woman enslaved to Major Richard Graham (1780-1857), who owned a farm nearby. Peter and Marian married and had three children: Elizabeth (b.1845), Gabriel (b.1847), and Thomas William (b.1849). The Queen and Hawkins families from Maryland, who now labored on the Jesuits' Missouri property, incorporated Peter into their fold, for they served as witnesses at his marriage and godparents to his children. Moreover, Peter appears to have adopted the Queen surname. ${ }^{46}$

In 1849, within the same year of the birth of Peter and Marian's youngest child, the Missouri Jesuits sold Peter away from his kin and made him work at the Jesuits' Saint Joseph College in Bardstown, Kentucky. Forced to leave his wife and children behind, Peter left a small sum of money for Marian to support herself and their three children, the oldest of whom was three years old. ${ }^{47}$ The Jesuits claimed that Peter and Marian's "presences greatly harm the

45 Garraghan, Jesuits of the Middle United States, 291; "Register of Students, 1848-1861," Bin 3.o110. SJC, MIS.3.007, JARC; Account Book 1, 1848-52, Box 3.0111. SJC, MIS.3.007. JARC; Account Book 2, 1849-54, Box 3.o111. SJC, MIS.3.007. JARC; Ledger, 1848-61, Box 3.0111. SJC, MIS.3.007. JARC; "St. Joseph's College, Financial Records," 1827-62, Saint Louis University Archives and Special Collections [hereafter SLU]; "St. Joseph's College, Financial Records," 1848-56, SLU; "St. Joseph's College Financial Records," 1849-61, SLU; “Consultors Meeting Minutes for the Missouri Vice Province" (1832), Missouri Province Collection, unprocessed collection, JARC; "Ledger of Saint Stanislaus House, 1840-57," Box 3.0146, volume 1. St. Stanislaus Collection, JARC; Ledger of the Missouri Mission 1836-51, Box 2.0147, Item 5. Office of the Treasurer Collection, unprocessed collection, JARC.

46 For more on enslaved people sponsoring one another in sacraments, see Schmidt, "Enslaved Faith Communities"; Louis Barada, "Bill of Sale for Peter," May 1, 1832, Box 3.0136, folder 26-"Office of Indian Affairs regarding Saint Francis Indian Seminary, 1819-1832." Saint Stanislaus Collection, JARC; Register of Marriages and Burials, Box 3.0373, Item \#38. St. Ferdinand's Collection in the Missouri Province Collection, unprocessed collection, JARC; "Old St. Ferdinand Records" (St. Ferdinand Parish, 1792-1856), Archdiocese of St. Louis Office of Archives and Records; Sara Gaylor, trans., Translations of Parish Records, 1792-1846, St. Charles Borromeo Church, 1992.

"Day Book, 1848-1854," Box 3.0143, volume 4. St. Stanislaus Collection, JARC. 
other slaves in the house of probation." 48 It is possible that Peter and Marian, discontented with their treatment, were encouraging their kin to resist the Jesuits, and that the Jesuits, feeling threatened, sold Peter away to prevent further unrest. Or, as the Jesuits frequently expressed in letters as a justification for sale, it is also possible Peter and Marian were behaving "immorally," and were, in the Jesuits' view, setting a bad example for other bondspeople. Jesuits had rules against separating enslaved families, but nevertheless they broke up families constantly. In part they did not fully recognize the extent of enslaved family and kin networks. While Jesuits were permitted to sell people who had acted immorally, and used this as justification for many such decisions, they often sold people because they felt threatened, or due to financial need. ${ }^{49}$

A few weeks after Peter's forced arrival in Bardstown, he ran away. Peter's separation from his family and the proximity of freedom in Indiana may have prompted him to take the calculated risk to run. He headed North toward Louisville, likely either to find freedom in Indiana, or reach the Ohio River to make his way back to his family. ${ }^{50}$ Verhaegen posted an ad in local papers offering a fifty-dollar reward for Peter "for his apprehension and safe confinement in the Bardstown jail." According to Verhaegen, Peter was "somewhat more polished than a common negro, and his vigorous frame shows that he has been well fed in Missouri." He "speaks fluently and smartly," perhaps evidence of his influence among bondspeople at the Florissant farm. ${ }^{51}$ Peter was caught, for on the same day as the publication of this advertisement, the consultors of the Missouri Vice-Province questioned in their minutes, "whether we ought to sell the slave Peter, who ran away and is now spending time in prison [in] (Louisville)." All agreed that "he should be sold." Peter was sold, and we do not know if he and his family ever saw one another again. ${ }^{52}$

About a month later, the consultors, trying to decide what to do with the revenue from Peter's sale, agreed to use the money to purchase an enslaved woman named Mary Hoppins Queen (bef.1830-aft.1861), who was married to the Jesuits' bondsman Augustine Queen (c.1826-86), but belonged to another owner, to prevent the possibility of the couple being broken apart in the future.

48 "Consultors Meeting Minutes for the Missouri Vice Province."

49 "Tertius Liber," 1832-73; ARSI, Miss., 1001-1, 39-42, trans. Timothy Kieras.

50 On the opportunities and risks involved in escaping slavery in the borderlands, see Matthew Salafia, Slavery's Borderland: Freedom and Bondage along the Ohio River (Philadelphia: University of Pennsylvania Press, 2013); R. J. M. Blackett, The Captive's Quest for Freedom: Fugitive Slaves, the 1850 Fugitive Slave Law, and the Politics of Slavery (Cambridge: Cambridge University Press, 2018).

$5^{1} \quad$ Peter Verhaegen, “\$50 Reward," The Louisville Daily Courier, November 13, 1849.

$5^{2}$ "Consultors Meeting Minutes for the Missouri Vice Province." 


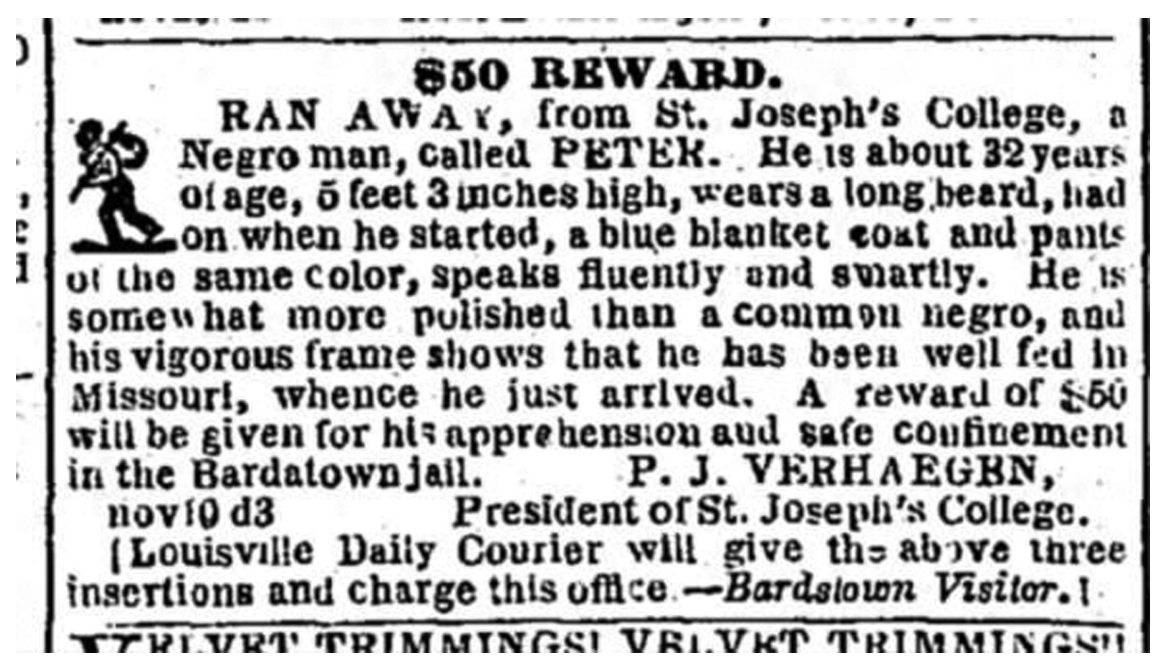

IMAGE 5.1 Runaway ad for Peter [Barada or Queen], placed in the Bardstown Visitor and the Louisville Daily Courier for three days from November 10-13, 1849. Peter's forced relocations by sale demonstrate both how Jesuits transferred enslaved people between their properties as they saw fit, and how inconsistently they upheld their regulations against separating families.

In such a way, one man's sale and forced separation from his family ensured the preservation of another family. ${ }^{53}$

Second middle passages like Peter's were common. ${ }^{54}$ Another woman, Mary (dates unknown), was forced from family in Missouri to labor in Bardstown in $185{ }^{\circ .55}$ And in Grand Coteau, Louisiana, sales and the stability of families depended upon the health of the Jesuit college.

\subsection{Saint Charles College, Grand Coteau, Louisiana}

Lyon and Missouri Province Jesuits relied upon enslaved labor in Grand Coteau, Louisiana, where they ran Saint Charles College beginning in 1837 .

53 Mary Hoppins Queen was the widow of Gabriel Queen, who was also held in slavery to the Jesuits. "Consultors Meeting Minutes for the Missouri Vice Province"; "Register of Marriages, 1813-1862; Register of Burials, 1813-1876," Box 3.0373, item 38. St. Ferdinand Parish Collection, JARC; "Bill of Sale of Mary," October 28, 1850, Box 3.o223, folder 7-Slavery 1850, 1862, 1872. Saint Louis University Collection, MIS 3.002, JARC.

54 In describing Peter's forced journey as a "second middle passage," I employ Ira Berlin's concept of Second Middle Passages, which he uses to describe the forced migrations of the internal slave trade in the United States. Ira Berlin, Generations of Captivity: A History of AfricanAmerican Slaves (Cambridge, MA: Belknap Press of Harvard University Press, 2003), 161-62.

“St. Joseph's College Financial Records," 1848-56, SLU. 
They borrowed enslaved people belonging to local owners and teachers at the college, as well as the Sisters of the Sacred Heart. In 1839, the Jesuits purchased three bondspeople of their own to support the college and the Jesuit community. Jesuits obtained Philodie, about age fifty (c.1789-1855), and Rachel (b. c.183o), her nine-year-old daughter, from Charles Napoleon Oliver (1811-58) and later sold them to two different owners: Rachel, about fourteen in 1844, to Nicholas Charles Grimmer (1814-54), music teacher at Saint Charles College, and Philodie to a Mr. Gara (dates unknown) in 1847, in clear disregard of their rules against separating families. The Jesuits also bought Ignatius Gough (c.1818-61), a young man of about twenty-one years of age who had been sold by Stephen H. Gough (a graduate of Georgetown University in 1830, dates unknown) in Maryland when Ignatius was seventeen. Ignatius endured his middle passage to the port of New Orleans packed in a hold alongside 142 other enslaved people on the brig Isaac Franklin in $1835 .{ }^{56}$

After his arrival at Saint Charles College, Ignatius Gough met and married a woman named Sally (c.1816-aft.19oo), who belonged to Pierce (1804-83) and Cornelia Connelly (1809-79), who taught English, music, and drawing at the College and nearby Academy of the Sacred Heart. Cornelia, who later became foundress of the Society of the Holy Child Jesus, is now considered venerable and a candidate for canonization in the Catholic Church. Ignatius and Sally had nine children together, about six of whom lived to adulthood. After the birth of their first child, James Henry (b.1840), local sheriffs imprisoned Ignatius Gough for suspected involvement in a plotted slave revolt. According to Pierce Connelly, Gough had been one of the several local enslaved people arrested because a loaded pistol had been "unluckily [...] put in his possession" by a brother running away from the Society, which was "accidentally discovered in his hands." ${ }^{57}$ After being incarcerated and interrogated for eight days,

$5^{6} \quad$ "Fr. Carbery requests a tax deduction for the value of seventeen slaves sold by the Maryland Jesuits, 1836," Georgetown Slavery Archive, from MSA, https://slaveryarchive.georgetown.edu/ items/show/311 (accessed June 6, 2020); Slave Manifests of Coastwise Vessels Filed at New Orleans, Louisiana, 1807-1860. NARA microfilm publication M1895, 30 rolls. Records of the U.S. Customs Service, Record Group 36. NARA, Washington, DC; Robert S. Smith, "Bill of Sale of Ignatius Gough," February 13, 1839, New Orleans Province Collection, unprocessed collection, JARC. "Bill of Sale for Philadie and Rachel," September 8, 1848, New Orleans Province Collection, unprocessed collection, JARC; Wendell Holmes Stephenson, Isaac Franklin: Slave Trader and Planter of the Old South (Baton Rouge, LA: Louisiana State University Press, 1938), 38; Garraghan, Jesuits of the Middle United States, 153-56; "Minister's Diary, St. Charles College”; “Historia Domus" (1837-1942), New Orleans Province Collection, unprocessed collection, JARC.

57 Connelly to Blanc, September 16, 1840, Archives of the University of Notre Dame, quoted in Garraghan, Jesuits of the Middle United States, 146. 
Ignatius, deemed innocent, returned to his family in time to see his son's baptism. Thirty others who were hanged were not as fortunate. ${ }^{58}$

It is not known to what extent Ignatius Gough may have been actually involved in plans for widespread resistance among the local enslaved population. Bondspeople near Saint Charles College had previously attempted uprisings, all of which had resulted in their apprehension and extensive court-ordered hangings and vigilante executions. By this point, it was not clear whether white reactions were to a real plot or were the result of mass hysteria. Solomon Northup (1808-63), however, in describing an enslaved conspiracy that had occurred in the region where Gough lived three years earlier, recounted that he had been part of multiple consultations over the course of his enslavement near Bayou Boeuf about the feasibility of renewed attempts to fight for freedom en masse. If the plans were real, Ignatius likely knew of them, regardless of the extent to which he participated. Records show that enslaved communication networks along the nearby Bayou Boeuf spanned seven Louisiana parishes. ${ }^{59}$ If he did not participate, Gough may have shared

$5^{8}$ "Executions in the U.S. 1608-2002: The ESPY File Executions by State" (Death Penalty Information Center, n.d.), https://files.deathpenaltyinfo.org/legacy/documents/ESPYstate. pdf (accessed June 6, 2020); “A Negro Revolt," The Times-Picayune, September 1, 1840; “A Revolt," The Evening Post, September 11, 1840; "Insurrection," Baton-Rouge Gazette, September 5, 1840; "Minister's Diary, St. Charles College"; "Historia Domus" (1837-1942), New Orleans Province Collection, unprocessed collection, JARC.

59 "Insurrection Quelled," The Evening Post, October 27, 1837, citing the New Orleans American; Niles Weekly Register, October 28, 1837; Acts of the State of Louisiana, March 12, 1838, 118-20; Solomon Northup and David Wilson, Twelve Years a Slave. Narrative of Solomon Northup, a Citizen of New York, Kidnapped in Washington City in 1841, and Rescued in 1853, from a Cotton Plantation near the Red River, in Louisiana (Auburn: Derby \& Miller, 1853), 248-49; "A Negro Revolt," The Times-Picayune, September 1, 1840, 2; "Negro Insurrection in Lafayette," The Times-Picayune, September 2, 1840, 2. The Times Picayune received its information from the Iberville Gazette "received last evening;" New Orleans Commercial Bulletin, September 3, 1840; "The Contemplated Negro Revolt in the Parish of Lafayette," Daily Picayune, September 5, 1840, 2; "A Revolt.," The Evening Post, September 11, 1840, 2; "The Slave Revolt," The Evening Post, September 14, 1840, copied from New Orleans Courier, September 1, 1840; "A Negro Revolt," Liberator, September 18, 1840, 151; “Insurrection," Niles' Weekly Register, September 19, 1840, which received its account from the New Orleans Bee of September 2, 1840. The Bee appears to have gotten this account from the New Orleans Courier of September 1, 1840; "The Insurgents," The Times-Picayune, September 19, 1840, 2, which obtained its account from the Plaquemine Gazette and the Vermillionville Gladiator, September 12, 1840; "Fruits of Slavery," Liberator, September 25, 1840, which received its account from St. Martinsville, Louisiana, on September 5, 1840; "Negroes Executed," Daily Picayune, September 30, 1840, repeated in "Items," Liberator, October 30, 1840, 176; "Revolt.," The Evening Post, September 12, 1840, 2; "Insurrection," Niles Weekly Register, October 10, 1840, citing the "Jour. of Con." Opelousas, Louisiana, September 4, 1840; "A Negro Plot," The Times-Picayune, October 30, 1840, 2; 
the sentiments of Northup, who voiced the risks inherent in such an uprising: "There have been times when a word from me would have placed hundreds of my fellow-bondsmen in an attitude of defiance. Without arms or ammunition, or even with them, I saw such a step would result in certain defeat, disaster and death, and always raised my voice against it." ${ }^{60}$ Perhaps out of concern for the safety of his family, Gough found other ways to resist his enslavement, such as when he slipped away from his expected labors to seek brief respite, and damaged the Jesuits' tools and properties. Ignatius was punished for his actions by spending two Sundays in the local prison on bread and water, just as his stepson, George-Joachim (b. c.1836), was when he defrauded the Jesuits. ${ }^{61}$

The Jesuits' advocacy on Ignatius's behalf may have been motivated by their own fears. Not only may Jesuits have been reluctant to lose valuable property, they were fearful of the consequences they might suffer if Ignatius was indicted. Local planters and law enforcement had imprisoned a handful of white men they believed to be abolitionists who had incited enslaved

"Insurrection," Niles' National Register, November 14, 1840, vol. 59, 176. The Niles' Register writes that its source was the New Orleans Correspondent of the Baltimore American, and that it received its information from the Opelousas Gazette; "Summary of News," Liberator, November 20, 1840, 187, citing the Natchez Gazette, reporting the prevented insurrection from October 24; Albert Biever, Diary, New Orleans Province Collection, unprocessed collection, JARC; Times-Picayune, New Orleans, February 5, 1841, 2; "Breaking up a Gang of Negroes," The Times-Picayune, October 30, 1846, 2; "Murder," Liberator, December 4, 1846, 194; Garraghan, Jesuits of the Middle United States, 145-46; Edward D. Reynolds, Jesuits for the Negro (New York: America Press, 1949); Charles S. Sydnor, "The Southerner and the Laws," The Journal of Southern History 6, no. 1 (1940): 3-23; David Grimsted, American Mobbing, 1828-1861: Toward Civil War (Oxford University Press, 1998); G. P. Whittington, "Rapides Parish, Louisiana," The Louisiana Historical Quarterly XVI (n.d.); Harvey Wish, “American Slave Insurrections Before 1861," The Journal of Negro History 22, no. 3 (1937): 299-320; Herbert Aptheker, American Negro Slave Revolts (New York: Columbia University Press, 1943), 325-39; Joseph Cephas Carroll, Slave Insurrections in the United States (Boston: Chapman \& Grimes, Inc., 1938); Joseph E. Holloway, "Slave Insurrections in the United States: An Overview," http://slaverebellion.info/index.php?page=united-states-insurrections\%2o (accessed June 6, 2020); Junius P. Rodriguez, "Complicity and Deceit: Lewis Cheney's Plot and Its Bloody Consequences," in Lethal Imagination: Violence and Brutality in American History, ed. Michael A. Bellesiles (New York: New York University Press, 1999); Terry L. Seip, "Slaves and Free Negroes in Alexandria, 1850-186o," Louisiana History: The Journal of the Louisiana Historical Association 10, no. 2 (1969): 147-65; Ulrich Bonnell Phillips, American Negro Slavery: A Survey of the Supply, Employment and Control of Negro Labor as Determined by the Plantation Regime (New York: D. Appleton, 1918; Vernie Alton Moody, "Slavery on Louisiana Sugar Plantations" (PhD diss., University of Michigan, 1924).

6o Northup, 239-40.

61 "Minister's Diary, St. Charles College." 
people to rebellion. They had the men beaten, threatened them with death, and ultimately drove them out of the state. The day after Father Theodore DeLeeuw (1819-98) went to check on Ignatius in prison, the community's superior received an anonymous letter from Lafayette, stating that the Jesuits were suspected of causing the insurrection. It declared that a volunteer contingent of about seventy-five young men would soon arrive to beat the Jesuits and then encamp themselves on the premises. The letter was apparently one of several that accused the Jesuits of having encouraged unrest, and one of several more from nativist, anti-Catholic Know-Nothings in the area who threatened the Jesuits with death or forced removal from the area. In addition, according to a later account, the Opelousas court had charged the Jesuits with supplying bondspeople with weapons and shaking hands with a Black man. Suspicion was further raised over a Jesuit having heard the confession of a relative of one of the bondspeople who led the plot. The vigilante Lafayette Volunteers and others threatened to lynch the Jesuits or drive them out of town. Fortunately for the Jesuits, their allies in Grand Coteau armed themselves and came to the Jesuits' defense. Hearing of this, the Lafayette Volunteers and other vigilante patrols stood down. Others, namely the enslaved people implicated and put to death, were not so fortunate. ${ }^{62}$ Thus, while the Jesuits' intervention on Ignatius's behalf protected him, it was also likely an attempt to defend themselves, dissociate from targeted abolitionists, and avoid facing the same fate.

In 1842, as Pierce and Cornelia Connelly prepared to leave for Rome so Pierce could join the priesthood, the Connellys sold Sally Gough and her children to the Jesuits. The Gough family labored at Saint Charles College until the school began to falter. At some point between $185^{1}$ and 186o, the Jesuits sold the Goughs to Dr. Henry Jackson Millard (1824-63), after most Jesuit faculty had left to focus their teaching efforts on Saint Joseph's College in Bardstown and Spring Hill College in Alabama. ${ }^{63}$

62 "Minister's Diary, St. Charles College"; Biever, Diary, 79; Reynolds, Jesuits for the Negro, 16364; Connelly to Blanc letter, cited in Garraghan, Jesuits of the Middle United States, $145^{-46 .}$

63 Pierce Connelly, "Bill of Sale of Sally and Children," September 14, 1842, New Orleans Province Collection, unprocessed collection, JARC; "Minister's Diary, St. Charles College"; "Black Baptisms Book 1," 1821-41, St. Charles Borromeo Church, Grand Coteau, Louisiana; United States of America, Bureau of the Census. Seventh Census of the United States, 1850. Washington, DC: NARA, 1850. M432; United States of America, Bureau of the Census. Eighth Census of the United States, 186o. Washington, DC: NARA, 186o. M653. 


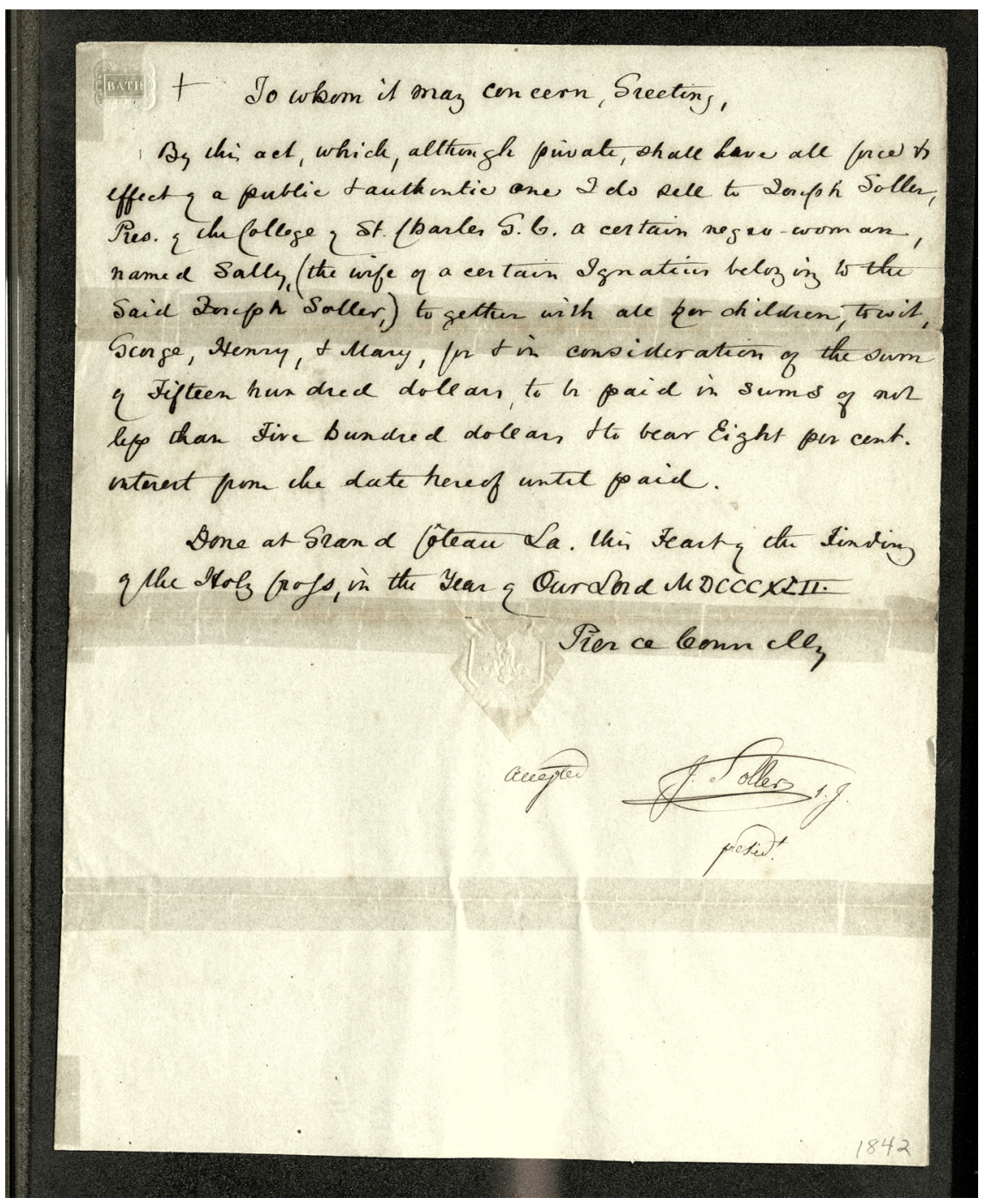

IMAGE 5.2 Enslaved people such as Sally Gough and her children George-Joachim, James Henry Mary, and Mary, were frequently exchanged between the Jesuits, lay Catholics, and other Catholic religious. The Gough family were no longer separated across plantations after Pierce Connelly sold Sally and her children to the Jesuits, formalized in this bill of sale, before he and Cornelia Connelly departed to pursue religious life.

IMAGE COURTESY OF THE JESUIT ARCHIVES \& RESEARCH CENTER, ST. LOUIS, MISSOURI 


\subsection{Inconsistent Attitudes, Common Legacy}

Reliance on enslaved labor was fundamental to the operation of Jesuit schools. Moreover, students' access to these schools was defined by the color of their skin. Students of color were not permitted to attend Saint Louis University in the nineteenth century. Three students of color were dismissed from Saint Joseph College for "having been proven to be of mixed blood." 64 Sons of white slaveowners and enslaved women from Louisiana attended Xavier University in Cincinnati, but when Xavier had to send away its boarding students due to financial distress in 1854, Jesuit William Stack Murphy (1803-75) wrote that while he could send white students to Saint Louis University and Saint Joseph College,

Cincinnati located in a state (Ohio) where slavery does not exist and where blacks are better received, several Louisianans sent children of mixed blood there, that is, [they are] more or less mulatto, and almost all illegitimate or born of marriages forbidden by civil law. Bardstown and Saint Louis could not receive them without breaking the law because the laws of Kentucky and Missouri, slave states, oppose it, and in any case all the white students would withdraw right away. Black and mixed blood finds liberty and equality only in Canada and Spanish America. 65

Murphy's commentary exemplifies how Jesuits cited the regional laws and attitudes of the populations they sought to serve to excuse the contradictory ways members of the Society regarded and treated people of color in different regions. While willing to educate mixed-race sons of the wealthy Southern Catholic planters who supported their institutions, but only in the North, where it was safer to do so, they rejected students of color in Southern states, where they feared reactions from students and parents, benefactors, and the local community.

Jesuits' effort to conform to the sentiments of the regions where they operated reflects Superior General Beckx's decree from Rome in 1861, after the outbreak of the Civil War, that American Jesuits adopt the government and attitudes of the states where they ministered. Some proudly served as Union and Confederate chaplains. In borderlands such as Missouri, Ohio, and Kentucky

\footnotetext{
64 "Register of Students, 1848-1861," Bin 3.0110. Saint Joseph College Collection, MIS.3.oo7, JARC.

65 ARSI, Miss., 1005-II, fol. 214 ${ }^{\mathrm{r}}$, trans. Steven Hawkes-Teeples and Kelly L. Schmidt.
} 
following prevailing sentiments was more difficult. Murphy ordered Missouri Province Jesuits not to take sides in the conflict, though many did so anyway. ${ }^{66}$

American Jesuits were not all of one mind about the issue of slavery. Some objected to it, though they never associated themselves with the largely anti-Catholic, anti-slavery abolitionist cause. ${ }^{67}$ Nevertheless, since the Jesuits believed in the ownership of all things in common, all Jesuits, regardless of their sentiments, were slaveowners.

\section{$2 \quad$ Moving Forward}

As evidenced by the depth of knowledge shared about enslaved people in some regions and the brief overviews given for others, our work continues. Jesuits were also immersed in the institution of slavery in New Orleans, Louisiana, and Mobile, Alabama, at Spring Hill College, but our research has more to uncover on these fronts, and others. We will continue to communicate our findings to the public as we learn more.

In addition to supporting descendants and Jesuits in seeking to repair historical harms together, part of our effort is also to educate Jesuits, Jesuit institutions, and the general public about their historical involvement in slaveholding, segregation, racism, and ongoing systemic issues today, and what their role should be in addressing these issues. The legacies of slavery, and the legacies descendants of the Jesuits' enslaved people have left, continue to shape our communities.

Matilda Tyler (c.1810-1901), a woman believed to be the daughter of Proteus and Anny Queen-Hawkins, one of the families brought from Maryland in 1829, and a bondswoman of Saint Louis University, purchased her own freedom and that of her five sons between 1849 and 1859. The money

66 Garraghan, Jesuits of the Middle United States, 147, 152-53, 156-58; Fortin, To See Great Wonders, 58; John T. McGreevy, Catholicism and American Freedom: A History (New York: W. W. Norton, 2003), 78, 82; C. Walker Gollar, "Jesuit Education and Slavery in Kentucky, 1832 to 1868," Register of the Kentucky Historical Society 108, no. 3 (2010): 611-47, here 639; Letter from Francis X. Weninger to Archbishop Purcell, n.d., Midwest Jesuit Archives (from Notre Dame Archives: 10807); Raymond H. Schmandt and Josephine H. Schulte, "Civil War Chaplains: A Document from A Jesuit Community," Records of the American Catholic Historical Society of Philadelphia 73, no. 1/2 (1962): 58-64; Sean Fabun, "Catholic Chaplains in the Civil War," The Catholic Historical Review 99, no. 4 (2013): 675-702; William B. Kurtz, "Priests and Nuns in the Army," in Excommunicated from the Union: How the Civil War Created a Separate Catholic America (New York: Fordham University Press, 2016), 68-88; James J. O’Brien, "Annals of Spring Hill College, Mobile, Ala., 1830-1914," Box oo214, JARC.

67 O'Brien, "Annals of Spring Hill College"; Garraghan, Jesuits of the Middle United States, 617. 
for her freedom went to Saint Francis Xavier College Church, where Matilda and her family were parishioners. Matilda's resistance to her enslavement to the Jesuits was not a rejection of the Catholicism her owners imparted. She adhered to her faith even as her owners and former owners increasingly segregated people of color from white parishioners within their churches. One year after becoming free, Matilda Tyler went to the same church whose operation was funded in part by the price of her freedom and received the sacrament of confirmation. By the time her sons had become free, the Tyler family and other Black Catholics could no longer worship from the back pews of the college church but had separate Masses in a small room in the upper gallery of the same church. ${ }^{68}$

Matilda Tyler's story speaks to the contemporary implications of our work. What did it mean for Matilda Tyler to earn her freedom, and what does it mean for the Jesuits to use the money she gave in this way? What did Matilda's faith mean to her that she remained a member of the very church that profited from her bondage? Matilda Tyler and her family utilized the kin, faith, and community networks they had forged on the Missouri frontier to carve out meaningful lives despite their enslavement. They remained active members of Saint Francis Xavier College Church, and later Saint Elizabeth's Parish, a Jesuit parish founded specifically for black Catholics in 1873 , for generations. Saint Elizabeth's Parish closed in 1951, and many of its parishioners became part of Saint Matthew's Parish, a Jesuit-run church in the Ville neighborhood of Saint Louis. ${ }^{69}$ Matilda Tyler and her family had become members of this Parish even earlier, for in 19o1, her obituary stated that funeral services would be held there. She, and many other former bondspeople are buried in Calvary Cemetery in Saint Louis, frequently in unmarked graves. ${ }^{70}$ Matilda's youngest son, Charles

68 "Financial Records, 1863-1874," Doc Rec ool oo19 oo13, Series 19 Box 85-Financial Records, SLU; Ledger of the Missouri Mission 1836-51, Box 2.0147, Item 5. Office of the Treasurer Collection, unprocessed collection JARC; "Missouri Mission Varia," n.d., Box 2.0157, item 2. Office of the Treasurer Collection, unprocessed collection, JARC; "Confirmations, First Communions, Members Lists, 1846-1872" (St. Francis Xavier College Church), Archdiocese of St. Louis Office of Archives and Records; "Consultors and Trustees Minutes," SLU; Garraghan, Jesuits of the Middle United States, 561; Koning file, JARC; "Work of Ours Among the Colored Folk of St. Louis," Province Newsletters IV (November 1922): 23; "Litterae Annuae," 1861-62, box 3.o226, folder 2, St. Louis University Collection, JARC. For more on the development of segregated worship spaces, see Schmidt, "Enslaved Faith Communities."

69 Jesuit Chronicle: 1823-1940," JARC; Garraghan, Jesuits of the Middle United States, 562; Jeffrey R. Dorr, "Race in St. Louis's Catholic Church: Discourse, Structures, and Segregation, 1873-1941" (Master's thesis, Saint Louis University, 2015), 45. For more on this transition see Schmidt, "Enslaved Faith Communities in the Jesuits' Missouri Mission," 78-81.

"Matilda Tyler Obituary," St. Louis Post-Dispatch, January 22, 1901. 
H. Tyler (1844-99), in partnership with descendants of other families once owned by the Jesuits, was an influential leader in St. Louis's black communities. A politician and saloonkeeper, he was a co-founder of Saint Louis' first black baseball team and promoted other means for African American advancement in the late nineteenth century. He remained a parishioner of Saint Matthew's Parish until his death. ${ }^{71}$

As we move forward with this project, we cannot forget that the labor of enslaved people in the new mission territory supported the growth of the Jesuit order. Bondspeople were at the center of the running of the Jesuits' parishes, their missions to Native Americans and settlers in the West, as well as the development of their educational institutions, including those established in the North. This is a story that does not end in 1865 . Many of the formerly enslaved remained Catholic and stayed in the same Jesuit-run communities in the regions where they had once been enslaved. How many of Matilda Tyler's descendants are still part of these communities and perhaps associated with the parishes and schools of the Society of Jesus now? How do we account for the membership of descendants in parishes, schools, and other institutions that were supported in their earliest years by the unfree labor of these descendants' ancestors, institutions which Jesuits continue to operate today? We must keep this history in mind as, through the Slavery, History, Memory, and Reconciliation Project, Jesuits, Jesuit institutions, and members of the Catholic Church seek reconciliation and begin dialogue about how we can make amends today.

The story of the Tyler family is just one of many instances that show how the legacy of slavery and slaveholding extends into the Jesuits' parishes, missions, and schools. As we have seen, Catholic churches and education under the Jesuits grew increasingly segregated over the course of the nineteenth century. Today, those historically black churches and schools often remain separate from predominantly white institutions and those that have not closed are often under-resourced. How included and supported do people of color feel in integrated, but predominantly white, Jesuit churches and schools? How are we

71 "Death Notices," St. Louis Globe-Democrat, October 23, 1899; "Regular Republican Ratification Meeting!," St. Louis Post-Dispatch, April 3, 1885; "Said on the Street: Candidates' Chances as Discussed by the People," St. Louis Post-Dispatch, April 2, 1885; James E. Brunson, III, The Early Image of Black Baseball: Race and Representation in the Popular Press, 1871-1890 (Jefferson: McFarland \& Company, Inc., 2009), 160, 185-86; "Diamond Dust," St. Louis GlobeDemocrat, May 8, 1883; "The Colored Champions Win," St. Louis Globe-Democrat, May 8, 1883; "Colored Colonists," St. Louis Globe-Democrat, April 16, 1879; "CCraps.' Description of a Peculiar Form of Gambling," St. Louis Post-Dispatch, February 21, 1881. 
supporting those most affected by the legacies of slavery in the neighborhoods where Jesuit institutions operate? To what extent are all students of Jesuit schools aware that they are the inheritors of an educational system that has been privileged through the legacy of reliance on enslaved labor? Through the Slavery, History, Memory, and Reconciliation Project, we can, with descendants leading, begin to determine what Jesuits, and Jesuit parishes, works, programs, services, and educational institutions are obligated to do for the descendant communities that they now serve. 